\title{
Electrochemical Studies on Complexation and Speciation of Copper(II) in ppb Level with 1,10-Phenanthroline in Aqueous Media
}

\author{
N. Nahar*, N. P. Mona and M. N. Abser \\ Department of Chemistry, Jahangirnagar University, Savar, Dhaka 1342, Bangladesh.
}

\begin{abstract}
Complexation and speciation of copper (II) in ppb level with 1,10-phenanthroline (L) in aqueous media have been investigated by differential pulse anodic stripping voltammetry using thin mercury film glassy carbon electrode (TMFGCE). The work was carried out at constant ionic strength of $0.01 \mathrm{~mol} \mathrm{dm}^{-3}$ using $\mathrm{NaNO}_{3}$ at ambient temperature. The $\mathrm{pH}$ was kept constant at $9.12 \pm 0.10$ by the addition of borate buffer. Applying the concept of DeFord and Hume, the stability constants of different species of copper with 1,10-phenanthroline were calculated from the variation of peak potential and diffusion current of simple and complexed metal ions under the present experimental conditions. It was found that copper(II) form three complexes (1:1, 1:2 and 1: 3; metal : ligand) with 1,10-phenanthroline. The overall stability constant of copper complexes, MLn can be defined as $\beta_{\mathrm{MLn}}=\left[\mathrm{ML}_{\mathrm{n}}\right] /\left[\mathrm{M}^{2+}\right][\mathrm{L}]^{\mathrm{n}}$ in which $\mathrm{M}^{2+}=\mathrm{Cu}^{2+}$ and $\mathrm{L}=1,10-$ phenanthroline; $\mathrm{n}$ is an integer. The values of the stability constant of different copper complexes with 1,10 -phenanthroline were found to be $10^{9.33}, 10^{15.10}$ and $10^{20.48}$ for $\mathrm{CuL}, \mathrm{CuL}_{2}$ and $\mathrm{CuL}_{3}$, respectively (the overall charges were omitted for simplicity). The high values of overall stability constant indicate that the complexes are highly stable. Using the values of stability constant of copper complexes and hydrolysis constant of copper, the percentage of all possible copper species under present experimental conditions were calculated.
\end{abstract}

Keywords: Electrochemical, Speciation, Complexation, Copper 1,10-phenanthroline.

\section{Introduction}

Copper, among other transition metal ions, is an active center of many enzymes. It is an essential component of the plant metalloenzymes i.e. diamine oxidase (DAO), ascorbate oxidase (AO), o-diphenol oxidase (DPO), Cyt $c$ oxidase and superoxide dismutase. Removal of copper by the chelating agent from these enzymes inactivates them. Copper deficiency in subterranean clover depressed DAO, AO, and DPO activities in all leaf blades as reported earlier (Loneragan et. al, 1982).

Copper deficiency in human usually leads to several diseases (Danks 1988). On the other hand, it becomes toxic to cells at its concentration surpasses certain natural level and this is called copper overload (Theophanides and Anastassopoulou 2002). The excessive copper can promote damage to cellular molecules and structures through free radicals formation such as super oxide anion $\left(\mathrm{O}_{2}^{-}\right)$and $\cdot \mathrm{OH}$ (Galaris and Evangelou 2002). $\mathrm{Cu}^{2+}$ cannot easily cross cell membranedue to its positive charge and hydrophilicity. But the mem

\footnotetext{
* Corresponding author: E-mail: naharn@bangla.net
}

brane permeable 1,10-phenanthroline has the structure of aromatic macro ring and the lipophilicity of 1,10-phenanthroline ligand can help to transport copper through biological membranes causes the excessive copper accumulation in cells.

Copper complexes containing 1,10-phenanthroline have received considerable interest in nuclic acid chemistry due to their various applications following the discovery of the chemical nuclease activity of $\mathrm{Cu}$ (phen) $)_{2}$ complex in presence of molecular oxygen and reducing agents. It can bind tightly to the minor groove of DNA and induce the cleavage via $\cdot \mathrm{OH}$ formed by the catalysis of copper (Sigman et al.1979). DNA fragmentation has been detected in isolated cell nuclei treated with $\mathrm{Cu}(\text { phen })_{2}$ (Burkitt et al. 1996). $\mathrm{Cu}(\text { phen })_{2}$ is known to promote $\mathrm{OH}$ formation from reducing agents and molecular oxygen by redox cycling and is therefore considered to be a suitable agent for the stimulation of ROS formation. 
1,10-phenanthroline have been widely used in biology, biochemistry, medicine, hydrochemistry, and sea hydrology in studying chelation and redox processes involving trace copper (Kosaka et. al.1998, Mahadevan \& Palaniandavar, 1998, Lovstad, 1988). The knowledge of chemical species and stability constants of copper (II) with 1,10-phenanthroline determined at such low concentrations is needed in order to understand the toxicity of copper(II). It is, therefore, intended to study the complexation and speciation of copper(II) in ppb level with 1,10-phenanthroline in aqueous media. The method, differential pulse anodic stripping voltammetry using thin mercury film electrode (TMFE) is applied for the determination and speciation of metal ions in environment at lower concentration (ppb or less).

\section{Materials and Methods}

\section{Equipment and Reagents}

The electrochemical measurements were performed by HQ2040 electrochemical analyzer, Advanced Analytics, USA. The analyzer is coupled with computer controlled magnetic stirrer and electrochemical cell consisting of three electrodes: $3 \mathrm{~mm}$ glassy carbon electrode, $\mathrm{Ag} / \mathrm{AgCl} . \mathrm{KCl}$ reference electrode and $\mathrm{Pt}$ counter electrode as described by Nahar et al, 1999. The stock solution of mercury(II) chloride $\left(\mathrm{HgCl}_{2}\right)$ was prepared by dissolving required amounts of $\mathrm{HgCl}_{2}$ into 0.1 mole $\mathrm{dm}^{-3} \mathrm{HCl}$ solution. This solution was used to prepare the mercury film on glassy carbon electrode. A $1000 \mathrm{ppm}(\mu \mathrm{g} / \mathrm{mL})$ stock solution of $\mathrm{Cu}(\mathrm{II})$ was prepared by dissolving required amounts of $\mathrm{CuSO}_{4}$ in $0.1 \mathrm{~mol} \mathrm{dm}^{-3}$ $\mathrm{HNO}_{3}$ solution. Other stock solution of 0.01 mole dm${ }^{-3} 1,10$ phenanthroline was prepared by distilled and deionized water which was filtered with $0.40 \mu \mathrm{m}$ membrane filter before the solution was prepared. Metal contamination was removed from 1,10-phenanthroline solution by shaking the solution with small quantities of $\mathrm{MnO}_{2}$ and filtering it with $0.40 \mu \mathrm{m}$ membrane filter. The ionic strength of the solution was maintained constant using $0.1 \mathrm{~mol} \mathrm{dm}^{-3} \mathrm{NaNO}_{3}$ $(99.99 \%)$ solution. The required standard solutions were prepared once a week by dilution of the stock solutions. All stock solutions were stored in the refrigerator at $4{ }^{\circ} \mathrm{C}$.

\section{Preparation of working electrode}

The mercury film coated glassy carbon electrode was used as working electrode in this electrochemical study. The film was prepared on properly polished and washed glassy carbon electrode in $10 \mathrm{~mL}$ of $1.0 \times 10^{-3} \mathrm{~mol} \mathrm{dm}^{-3}$ mercury(II) solution. The solution was purged with nitrogen for 10 minutes to remove dissolved oxygen. Then the electrodes were connected to the analyzer. Any bubbles adhering to the electrodes were removed by tapping them off. The mercury film deposition was done at $-400 \mathrm{mV}$ for $6 \mathrm{~min}$ by applying differential pulse voltammetry program.

\section{Measurement of complexation of $\mathrm{Cu}$ (II) with 1,10- phenanthroline}

To measure the complexation of copper(II) with 1,10phenanthroline, first the electrochemical cell was assembled with $5 \mathrm{~mL}$ of $0.02 \mathrm{~mol} \mathrm{dm}^{-3}$ borate buffer having $\mathrm{pH} 9.12 \pm$ $0.10,1 \mathrm{~mL}$ of $0.1 \mathrm{~mol} \mathrm{dm}^{-3} \mathrm{NaNO}_{3}$ and $4 \mathrm{~mL}$ of distilled and deionized water. The solution was then purged with pure nitrogen for 10 minutes. The background voltammogram was obtained using the following run conditions for differential pulse anodic stripping voltammetry:

Mode, stripping; initial potential, $-650 \mathrm{mV}$; final potential, $100 \mathrm{mV}$; gain (1-20), 10; deposition time, $120 \mathrm{~s}$; quite time delay, $30 \mathrm{~s}$.

The voltammograms of $\mathrm{Cu}(\mathrm{II})$ were obtained after successive addition of $20 \mathrm{ppb}(\mu \mathrm{g} / \mathrm{L})$ of $\mathrm{Cu}(\mathrm{II})$ in the cell under the above experimental conditions. A linear calibration was obtained. To study the complexation capability of $\mathrm{Cu}$ (II) with organic ligands, an aliquot of $10 \mathrm{~mL}$ solution of $200 \mathrm{ppb}$

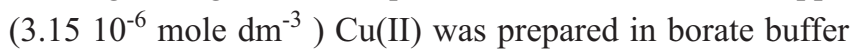
having $\mathrm{pH} 9.12 \pm 0.10$ and ionic strength $0.01 \mathrm{~mol} \mathrm{dm}^{-3}$ $\left(\mathrm{NaNO}_{3}\right)$. The solution was purged with nitrogen gas for 10 minutes to remove dissolved oxygen. The voltammogram of free $\mathrm{Cu}(\mathrm{II})$ was recorded using the same run conditions for DPASV as described above. The process was repeated for 3 times to check the reproducibility. An aliquot of $20 \mu \mathrm{L}$ of $1.04 \times 0^{-4}$ mole $\mathrm{dm}^{-3} 1,10$-phenanthroline was added to the cell and the solution was stirred for 60 seconds. The DPASV run was performed again under the same experimental conditions. The peak potential shifted to less negative value and peak height reduced due to the addition of 1,10-phenanthroline. The process was continued after successive addition of 1,10-phenanthroline in it, until constant peak potential and peak height were obtained. 


\section{Theory for data treatment}

In presence of any organic ligand $\mathrm{L}$, the free metal ion forms complexes as follows:

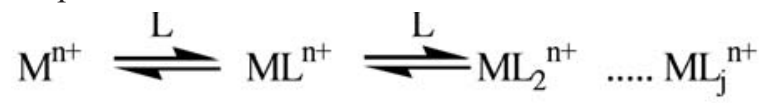

Measurement of peak current and change in peak potential induced by increasing ligand concentration allows the determination of total conditional stability constant of complexes in solution. According to the concept of DeFord and Hume (DeFord and Hume, 1951) the change in peak potential with ligand concentration is related to the successive stability constant as follows:

$\mathrm{F}_{0}=\exp \left(-\frac{n F}{R T} \Delta E+\ln \frac{I_{\text {free }}}{I_{\text {complexed }}}\right)=1+\sum_{i=1}^{N} \beta_{i}[L]^{i}$

Where, $\Delta \mathrm{E}=(\mathrm{E})_{\mathrm{s}}-(\mathrm{E})_{\mathrm{c}},(\mathrm{E})_{\mathrm{s}}=$ peak potential of simple metal ion and $(\mathrm{E})_{\mathrm{c}}=$ peak potential of complex metal ion; $\mathrm{n}=$ number of electron involve in half reaction, $\mathrm{F}=$ Faraday constant, $\mathrm{R}=$ gas constant, $\mathrm{I}_{\text {free }}=$ diffusion current of free metal ion, $\mathrm{I}_{\text {complexed }}=$ diffusion current of complex metal ion, The successive formation constants $\left(\beta_{\mathrm{i}}\right)$ are evaluated by polynomial fitting of the zero-order Leden function $\mathrm{F}_{0}$. The values of $\mathrm{F}_{0}$ can be calculated from the experimental change in peak potential and peak currents for each values of [L] in the voltammetric titration using equation 2 . From the observed change in potential $\Delta \mathrm{E}$, the various $\mathrm{F}_{0}$ can be calculated for each values of free ligand concentration, [L]. Free ligand concentrations, [L] were computed from the experimental $\mathrm{pH}$ values by taking literature values of protonation constants (Martell and Smith, 1982), and neglecting the bound ligand with proton.

Thus, $[\mathrm{L}]=\mathrm{C}_{\mathrm{L}}\left(1+\left[\mathrm{H}^{+}\right] K_{1}+\left[\mathrm{H}^{+}\right]^{2} K_{1} K_{2}\right)^{-1}$

Where, $\mathrm{C}_{\mathrm{L}}$ represents the total concentration of ligand and $K_{1}$ and $K_{2}$ are the protonation constants of the ligand. The overall conditional stability constant of each species is determined using polynomial fitting program on Equation 2. The actual value of the overall stability constant is obtained by considering the inorganic side reaction coefficient of copper $\left(\alpha_{\mathrm{Cu}}\right)$ at $\mathrm{pH} 9.12 \pm 0.10$.

\section{Result and Discussions}

The complexation of copper(II) with 1,10-phenanthroline were studied by differential pulse anodic stripping voltam- metry at constant ionic strength $(I=0.01)$ at $\mathrm{pH} 9.1 \pm 0.1$. From the effect of deposition time, potential range and $\mathrm{pH}$, the optimum parameters were selected for copper(II) complexation. Using the optimum parameters, the calibration curves i.e. the plots of diffusion current against copper concentration was found to be linear for copper(II) shown in Figure 1, indicating the reduction of metal to metal mercury is diffusion controlled.

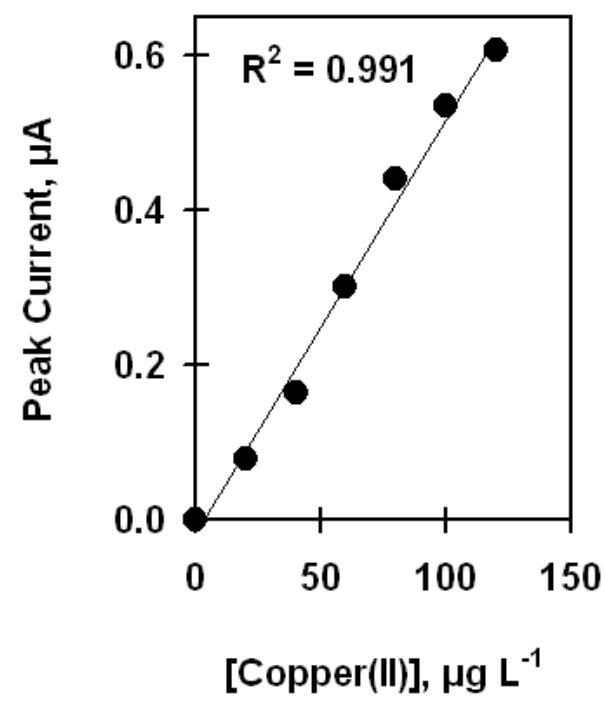

Fig. 1: Calibration plot for the quantification of copper (II) by DPASV using mercury thin film glassy carbon electrode in aqueous solution at $\mathrm{pH}$ $9.12 \pm 0.1$ and $I=0.01 \mathrm{~mol} \mathrm{dm}^{-3}$.

A typical change of voltammograms with ligand $(1,10$ phenanthroline) concentration is shown in Figure 2. The peak of the unchelated copper(II) appeared at $-0.16 \mathrm{~V}$, under the present experimental conditions in absence of 1,10 phenanthroline. The diffusion current $\left(\mathrm{I}_{\mathrm{d}}\right)$ of $\mathrm{Cu}$ (II) ion gradually decreased by the addition of 1,10-phenanthroline due to the formation of kinetically inert metal-ligand complexes shown in Figure 2. The term, 'inert complex' indicates the metal-ligand complex in which kinetics of dissociation is very slow compared to the time of the DPASV measurements. The plot of peak potential (E) vs $\log \mathrm{i} /\left(\mathrm{i}_{\mathrm{d}}-\mathrm{i}\right)$ was found to be linear shown in the Figure 3 , indicating the reduction of copper to $\mathrm{Cu}(\mathrm{Hg})$ on the mercury film electrode is a reversible process. The plot of peak potential (E) vs. log $[1,10 \text {-phenanthroline }]_{\text {total }}$ for copper(II) found to be a smooth curve (Figure 4) indicating the formation of two or more complexes which are in equilibrium with each other. 


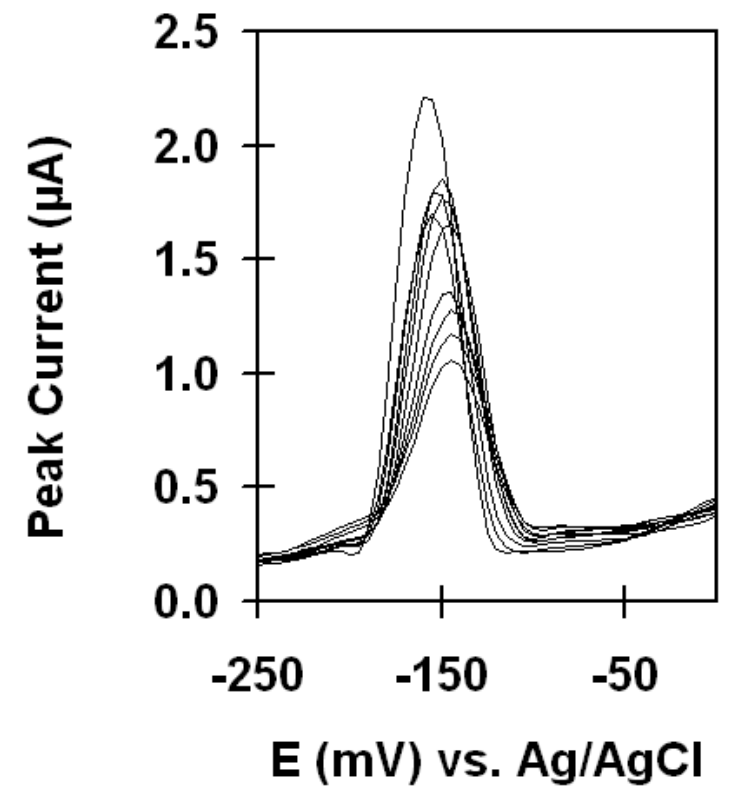

Fig. 2: Voltammograms of copper after successive addition of varying concentration of 1,10-phenanthroline (Phen); [Cu (II)] = $3.56 \mu \mathrm{M}$, [Phen] $=$ 0.00 to $2.04 \mu \mathrm{M}, \mathrm{pH}=\mathbf{9 . 1 2} \pm 0.1$ and $I=0.01 \mathrm{~mol}$ $\mathrm{dm}^{-3}\left(\mathrm{NaNO}_{3}\right)$.

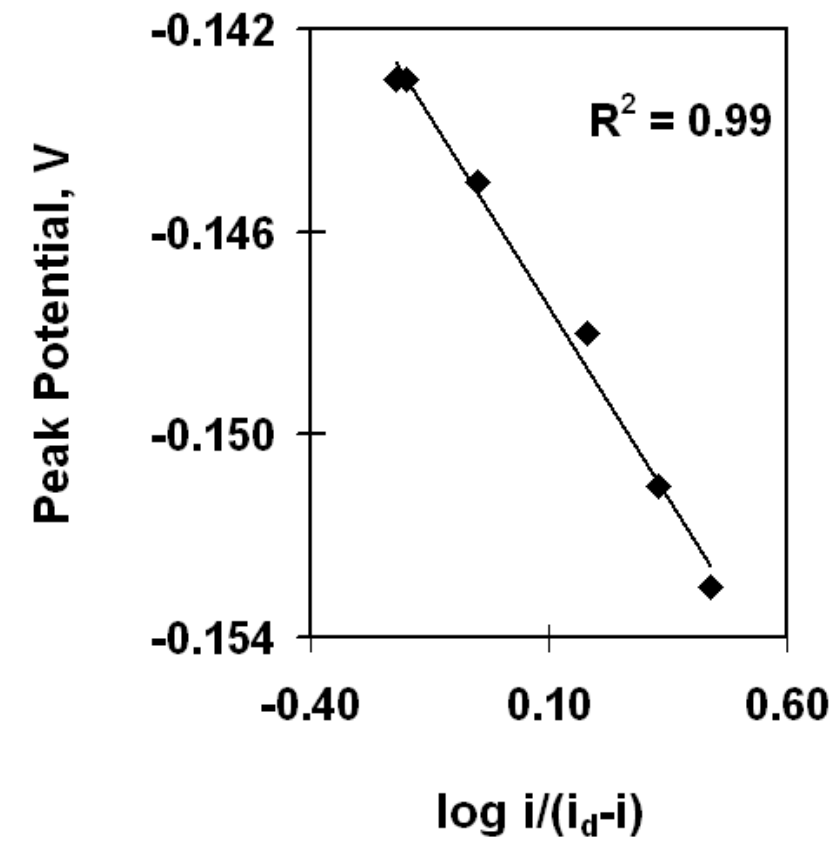

Fig. 3: A plot of peak potential vs. $\log i /\left(i_{d}-i\right)$ for copperphenanthroline complexes when $[\mathrm{Cu}(\mathrm{II})]=\mathbf{3 . 5 6}$ $\mu \mathrm{M},[$ Phen] $=\mathbf{0 . 0 0}$ to $2.04 \mu \mathrm{M}, \mathrm{pH}=\mathbf{9 . 1 2} \pm \mathbf{0 . 1}$ and $I=0.01 \mathrm{~mol} \mathrm{dm}^{-3}\left(\mathrm{NaNO}_{3}\right)$.
The zero order Leden function $\mathrm{F}_{0}$ was calculated according to the DeFord and Hume method as already described. The plot of $F_{0}$ vs. [1,10-phenanthroline $]_{\text {free }}$ shown in Figure 5, gives the values of conditional stability constants of individual complexes.

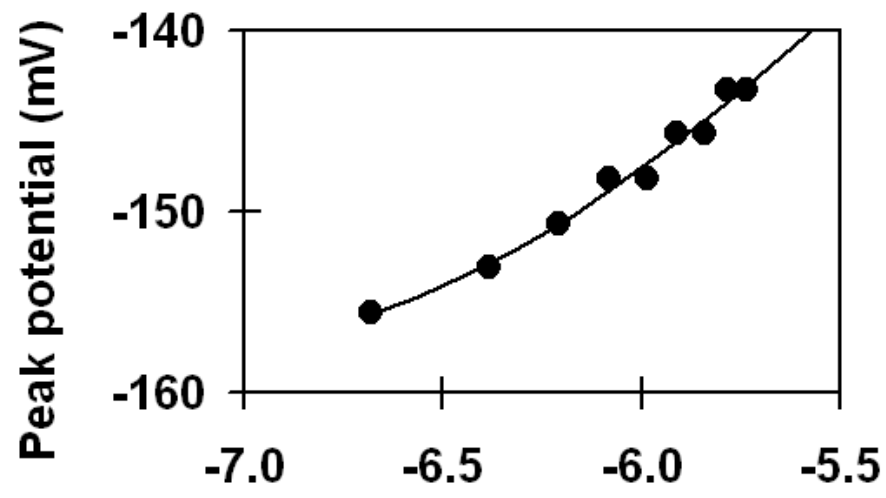

log [1,10-Phenanthroline]

Fig.4: Plot of peak potential vs. $\log [1,10$-phenanthroline (Phen) $]_{\text {free }} ;[\mathrm{Cu}(\mathrm{II})]=3.56 \mu \mathrm{M}, \mathrm{pH}=9.12 \pm$ 0.1 and $I=0.01 \mathrm{~mol} \mathrm{dm}^{-3}\left(\mathrm{NaNO}_{3}\right)$.

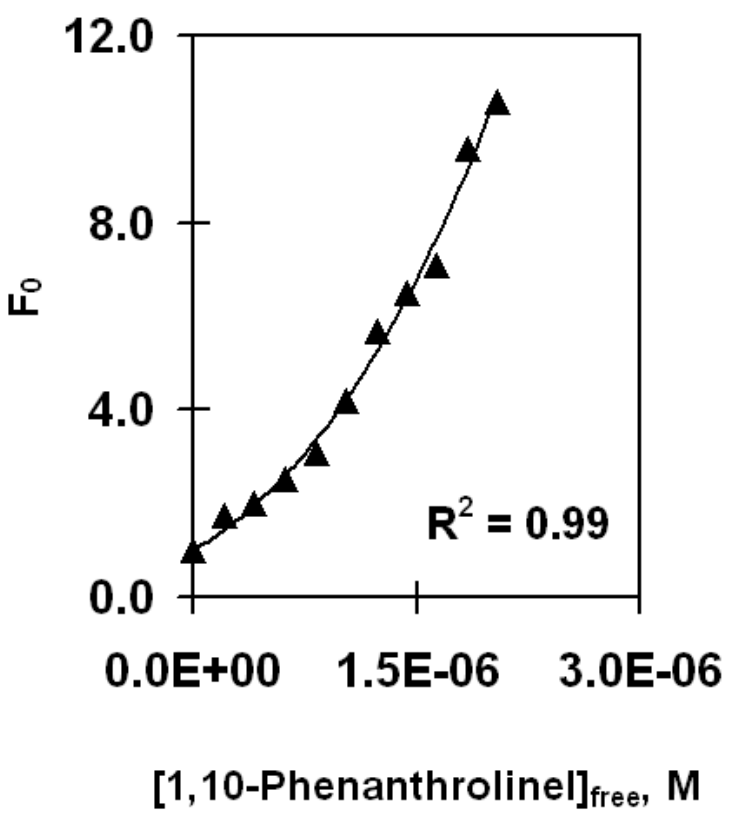

Fig. 5: The variation of $F_{0}$ as a function of concentration of free 1,10-phenanthroline (Phen); $[\mathrm{Cu}(\mathrm{II})]=3.56 \mu \mathrm{M}, \quad \mathrm{pH}=9.12 \pm 0.1$ and $I=$ $0.01 \mathrm{~mol} \mathrm{dm}^{-3}\left(\mathrm{NaNO}_{3}\right)$ 
The formation of three metal-ligand complexes, $\mathrm{ML}_{1}, \mathrm{ML}_{2}$ and $\mathrm{ML}_{3}$ (where $\mathrm{M}$ represents copper and L represents 1,10phenanthroline) are found under the experimental conditions. In the present experiment, DPASV technique detect the labile species which consist of free hydrated form (i.e. aqua metal ion, $\mathrm{M}^{2+}$ ) and hydroxo complexes $\left(\mathrm{M}^{+} \mathrm{OH}\right.$, $\mathrm{M}(\mathrm{OH})_{2}$ and $\left.\mathrm{M}(\mathrm{OH})_{3}{ }^{-}\right)$. This means that the technique gives a conditional constant that takes into account the side reaction of metal. Thus, it is necessary to consider the side reaction of $\mathrm{Cu}^{2+}$ with $\mathrm{OH}^{-}$at experimental $\mathrm{pH}$. The actual value of the overall stability constant is obtained by considering the inorganic side reaction coefficient of copper $\left(\alpha_{\mathrm{Cu}}\right)$ at $\mathrm{pH}$ 9.10 and neglecting the hydrolyzed form. The values of $\alpha_{\mathrm{Cu}}$ can be computed from the following expression. of 1,10-phenanthroline $K_{1}=[\mathrm{HL}]\left[\mathrm{H}^{+}\right]^{-1}[\mathrm{~L}]^{-1}=10^{4.93}$ and $K_{2}=\left[\mathrm{H}_{2} \mathrm{~L}\right][\mathrm{HL}]^{-1}\left[\mathrm{H}^{+}\right]^{-1}=10^{1.5}$, about $99.99 \%$ neutral (free form) is possible to exist at $\mathrm{pH} 9.10$. It is known that copper forms 1:1, 1:2 and 1:3 (metal: ligand) complexes with free form of phenanthroline (L) whose stability constants have been reported (Martell and Smith, 1982).

In the present investigation, the logarithmic values of overall stability constant of copper complexes with 1,10-phenanthroline are found to be 9.33, 15.10 and 20.48 for $\mathrm{CuL}, \mathrm{CuL}_{2}$ and $\mathrm{CuL}_{3}$, respectively. These values are very similar to the values reported before as shown in the Table I.

In laboratory conditions, trace amount (200 ppb or $3.15 \mu \mathrm{M})$ of copper was investigated in which free and hydrolysed

Table I: Stability constants of copper complexes with 1,10-phenanthroline

\begin{tabular}{l|c|c|c|c|c|c}
\hline Copper Complexes & Ionic strength, $\mathrm{mol} \mathrm{dm}^{-3}$ & Temp. ${ }^{\circ} \mathrm{C}$ & $\log \beta_{1}$ & $\log \beta_{2}$ & $\log \beta_{3}$ & References \\
\hline \multirow{2}{*}{ Copper complexes } & 0.01 & 30 & 9.33 & 15.1 & 20.5 & This work \\
& 0.10 & 25 & 9.08 & 15.8 & 21.0 & (Martell and \\
& 0.50 & 25 & 9.16 & $\begin{array}{c}\text { Smith, 1982) } \\
\text { Smith, 1982) }\end{array}$ & (Martell and \\
\hline
\end{tabular}

$\alpha_{\mathrm{Cu}}=1+\beta_{1}{ }^{\mathrm{OH}}\left[\mathrm{OH}^{-}\right]+\beta_{2}{ }^{\mathrm{OH}}\left[\mathrm{OH}^{-}\right]^{2}+\beta_{3}{ }^{\mathrm{OH}}\left[\mathrm{OH}^{-}\right]^{3}$

where, $\beta_{1}{ }^{\mathrm{OH}}, ., \beta_{3}{ }^{\mathrm{OH}}$ are the overall hydrolysis constants of copper.

Using the hydrolysis constants of copper, the value of the side reaction coefficient, $\alpha_{\mathrm{Cu}}$ was found to be 1150.7 at $\mathrm{pH}$ 9.10 .

Considering the inorganic side reaction coefficient of copper, the overall stability constants were calculated and listed in Table I. The large values of overall formation constants indicate that the complexes of copper (II) with 1,10-phenanthroline in alkaline $\mathrm{pH}$ are highly stable.

According to the hydrolysis constants of copper, mono-, diand tri- hydroxy species are possible to be formed. But in the present experimental conditions, $4.56 \% \mathrm{CuOH}^{+}, 95.29 \%$ $\mathrm{Cu}(\mathrm{OH})_{2}$ and $0.06 \% \mathrm{Cu}(\mathrm{OH})_{3}$ exist at $\mathrm{pH} 9.1$. The remaining part exists as aqua copper ion $\left(\mathrm{Cu}^{2+}\right)$ in absence of ligand. 1,10-phenanthroline (L) contains the electron donor atom, N. It can be monoprotonated (HL) or diprotonated $\left(\mathrm{H}_{2} \mathrm{~L}\right)$ depending on $\mathrm{pH}$ and the protonation constant. The distribution of different species of 1,10-phenanthroline in aqueous media with the variation of $\mathrm{pH}$ is shown in Fig. 6. Since the first and second protonation constant

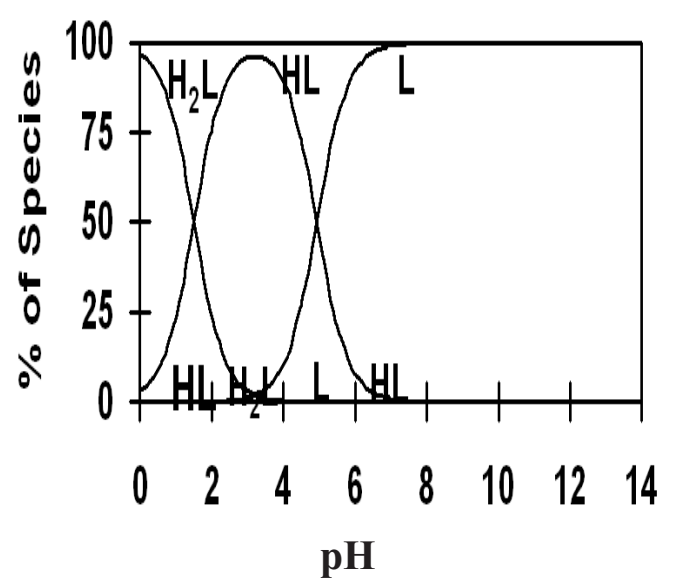

Fig. 6. Species distribution of 1,10-phenanthroline as a function of $\mathrm{pH}$.

forms are possible to exist in absence of ligand and hydrolysed as well as metal-ligand complexes are possible to exist in presence of ligand at $\mathrm{pH}$ 9.1. The percentage of all chemical species are calculated and shown in Figure 7 for copper phenanthroline complexes. The species distribution diagram shown in Figure 7 is of great help in the interpretation of voltammetric results and is used to confirm or reject a proposed metal-ligand model. All the above indicates that DPASV may be a powerful tool in trace metal speciation studies. 


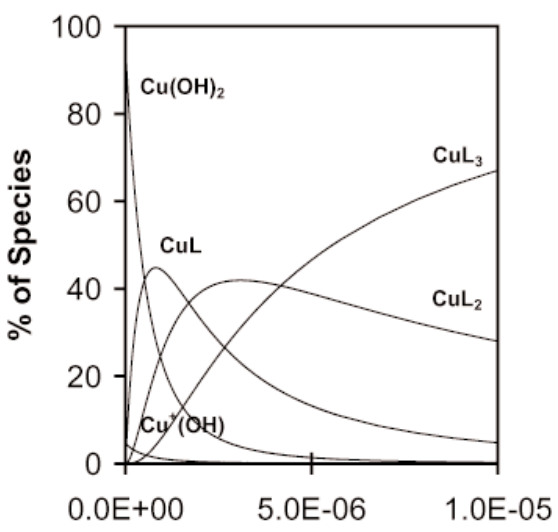

[1,10-Phenanthroline], M

Fig. 7: Species distribution of copper as a function of concentration of 1,10-phenanthroline at $\mathrm{pH} 9.1 \pm 0.1$

\section{Conclusion}

The complexation and speciation of copper(II) was investigated by DPASV in presence of 1,10-phenanthroline. It was found that trace amount of copper(II) is able to form 1:1, 1:2 and 1:3 (metal: ligand) complexes with 1,10-phenanthroline depending on $\mathrm{pH}$ as well as concentration of ligand. The formation constants obtained in this work are in good agreement with those reported before (Martell and Smith, 1982). In absence of ligand, about $95.3 \%$ copper exists as $\mathrm{Cu}(\mathrm{OH})_{2}$, whereas, in presence of any complexing ligand, it forms different complexes depending on ligand concentration. The large values of overall stability constant indicate that the complexes are highly stable. All species of copper co-exist within ligand concentration up to $1 \times 10^{-5} \mathrm{~mol} \mathrm{dm}^{-3}$ under the present experimental condition.

\section{Acknowledgement}

The authors gratefully acknowledge the Ministry of Information and Science \& Communication Technology, People's Republic of Bangladesh for financial support.

\section{References}

Burkitt M. J., Milne L, Nicotera P and Orrenius S. (1996). 1,10-Phenanthroline stimulates internucleosomal DNA fragmentation in isolated rat liver nuclei by promoting the redox activity of endogrnous copper ions. Biochem J 313: 163-170.

DeFord D. D. and Hume D. N. (1951). The Determination of consecutive formation constants of complex ions from polarographic data. J. Amer. Chem. Soc., 73: 5321-5322.

Danks D. M. (1988). Copper deficiency in humans. Annu Rev. Nutr. 8: 235-257.
Galaris D. and Evangelou A. (2002). The role of oxidative stress in mechanisms of metal-induced carcinogenesis. Crit.Rev oncol Hematol 42: 93-103.

Kosaka K., Yamada H., Matsui S., Echigo S. and Shishida K. (1998). Comparison among the Methods for Hydrogen Peroxide Measurements To Evaluate Advanced Oxidation Processes: Application of a Spectrophotometric Method Using Copper(II) Ion and 2,9Dimethyl-1,10-phenanthroline Environ. Sci. Technol, 32 (23): 3821-3824.

Loneragan J. F., Delhaize E. and Webb J. (1982). Enzymic diagnosis of copper deficiency in subterranean clover. I. Relationship of ascorbate oxidase activity in leaves to plant copper status; Australian Journal of Agricultural Research 33(6) 967 - 979.

Løvstad R. A. (1988). Interaction of neocuproine, 1,10phenanthroline and 2,2'-dipyridyl with human ceruloplasmin, Int. J. Biochem., 20: 117-119.

Mahadevan S. and Palaniandavar M. (1998). Spectroscopic and Voltammetric Studies on Copper Complexes of 2,9-Dimethyl-1,10-phenanthrolines Bound to Calf Thymus DNA, Inorg. Chem., 37 (4): 693-700.

Martell A. E. and Smith R. M. (1982). Critical Stability Constants, Plenum Press, New York. 5: 254.

Nahar N. Chowdhury, M. N. and Khan A. H. (1999). Complexation and chemical speciation of trace metals in aqueous media. J. Bang. Chem. Soc., 12: 173-183.

Nahar N. (2003) (a) Electrochemical study of speciation of lead(II) in aqueous solution in ppb level in presence of cysteine. Jahangirnagar University Journal of Science, 26: 55-66.

Nahar N. (2003) (b) Electrochemical studies of copper(II) complexation capacity and speciation in lake and river water. J. Bang. Chem. Soc., 16(2): 154-164.

Sigman D. S., Graham D. R., D'Aurora V. and Stern A. M. (1979). Oxygen-dependent cleavage of DNA by the 1,10-phenanthroline cuprous complex. Inhibition of Escherichia coli DNA polymerase I. J Biol Chem 254: 12269-12271.

Theophanides T. and Anastassopoulou J. (2002). Copper and carcinogenesis. Crit Rev Oncol Hematol 42: 57-64.

Received: July 01, 2010;

Accepted : November 25, 2010 